\title{
シーリング目地の交差部の耐剪断疲労性の評価 \\ EVALUATION OF FATIGUE RESISTANCE OF SEALANT TO SHEAR MOVEMENT AT CROSS AREA OF SEALED JOINT
}

\author{
宮内博之*, 田中享二** \\ Hiroyuki MIYAUCHI and Kyoji TANAKA
}

\begin{abstract}
Fatigue resistance of straight area in sealed joint design has been mainly evaluated, but there is a lot of cross area of sealed joint in actual building. Fatigue resistance of sealant to shear movement at cross area of sealed joint was studied experimentally and analytically. Three kinds of sealant were evaluated. The cross joint specimen and straight joint one were repeatedly deformed by shear movement. As a result, the cracks appeared at corner area earlier than the straight area. Moreover, it was shown that the stress of sealant was concentrated at corner area by using the finite element analysis. It was made clear that corner area of sealed joint provided lower shear fatigue resistance than the straight area of it.
\end{abstract}

Keywords : Sealant, Fatigue resistance, Joint, Corner, Shear movement, Stress Concentration シーリング材、耐疲労性、目地、隅角、剪断ムーブメント、応力集中

\section{1.はじめに}

前報 1)-2) では、シーリング材の耐剪断疲労性に及ぼす断面寸法、断 面形状について検討を行い、建物の目地の中で最も多くの面積を占め る直線的な目地である一般目地を対象とした剪断疲労試験方法の提 案を行った。しかし、実際の建物では、一般目地以外にも、表 $1 、 及$ び図 1 に示すような十字目地、T字目地、L字目地などの交差目地が 見られ、これらの目地には隅角部が必ず存在する。ここで、外力によ りムーブメントが生じた場合、目地の形状が急激に変化する隅角部付 近で応力分布の片寄りが生じ、その結果、耐疲労性に影響を及ぼすと 考えられる。

これら交差目地において、どの程度而疲労性が低下するのかは、工 学的観点からほとんど検討されておらず、目地幅の変更も実際には考 慮されていない状況にある。また、先の阪神・淡路大地震の際に見ら れたように、そのムーブメントは非常に大きかったにせよ、剪断ムー ブメントによるシーリング目地隅角部での損傷は多く見られ、この検 討は目地設計の観点からは非常に重要と思われる。

これらの背景を踏まえ、本研究では、剪断ムーブメントに対する交 差目地の耐疲労性について検討することを目的とし、一般部に対する 隅角部の応力集中の度合いと、応力レベルの違いがどの程度耐披労性 に影響を及ぼすのかについて調べた。

\section{表 1 目地及び耐疲労性の検討笛所の名称の定義}

\begin{tabular}{|c|c|c|}
\hline \multicolumn{2}{|c|}{ 目地の名称 } & 耐疲労性の検討簀所の名称 \\
\hline \multicolumn{2}{|l|}{ 一般目地 } & 一般部 \\
\hline \multirow{3}{*}{ 交差目地 } & 十字目地 & \multirow{3}{*}{ 隅角部 } \\
\hline & $\mathrm{T}$ 字目地 & \\
\hline & L字目地 & \\
\hline
\end{tabular}

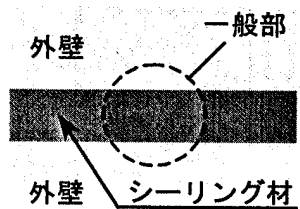

一般目地

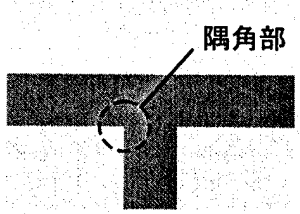

T字目地（交差目地）

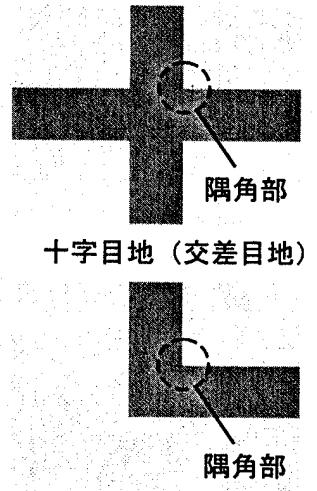

L字目地（交差目地）
図 1 一般目地と交差目地の形態、及び而疲労性の検討䉒所
* 東京工業大学建筑物理研究センター・助手 $:$ 工修

** 東京工業大学建築物理研究センター 教授. 工博
Res. Assoc., Structural Engineering Research Center, Tokyo Institute of Technology, M. Eng.

Prof., Structural Engineering Research Center, Tokyo Institute of Technology, Dr. Eng. 
既往の研究については、前報で述べたように、シーリング材の剪断

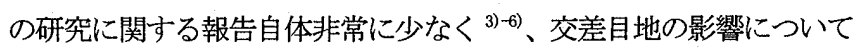

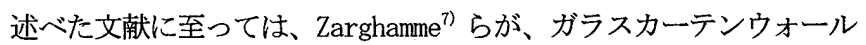
に施工されたシリコーン系シーリング材の地震時の挙動について検 討し、剪断ムーブメントによってその十字目地の亀裂が発生したこと を報告しているのみである。つまり、一般目地以外の目地の耐久性に ついての研究は殆どなされていないのが実状である。

\section{2. シーリング目地形態の違いによる耐疲労性の評価にあたって}

建物の外壁の形態によって、シーリング目地の形態は多少異なって くるが、大きくシーリング目地形態を分類すると、一般目地、十字目 地、T字目地、L字目地に分けられる。しかし、目地の交差部が存在 するかしないかの分類と考えれば、一般目地は交差部の存在しない目 地、一般目地以外の目地である十字目地などは、交差目地として大別 できる。これは、交差目地の形態が異なっても、応力の大小で目地の 耐疲労性を評価できると考えられる。本研究では、交差目地の影響を

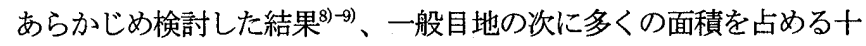
字目地を交差目地の代表的目地として取り上げ、一般目地と共に応力 集中の度合いや耐疲労性の影響について検討を行った。

\section{3. 疲労試験における十字目地の面剪断疲労性 \\ 3. 1 試験体}

一般目地と十字目地を模した試験体を図 2 に示す。

試験体の形としては、地震力・風力を受けた場合に発生する剪断么 ーブメントを再現できる最小限のものである。また、長手方向の目地

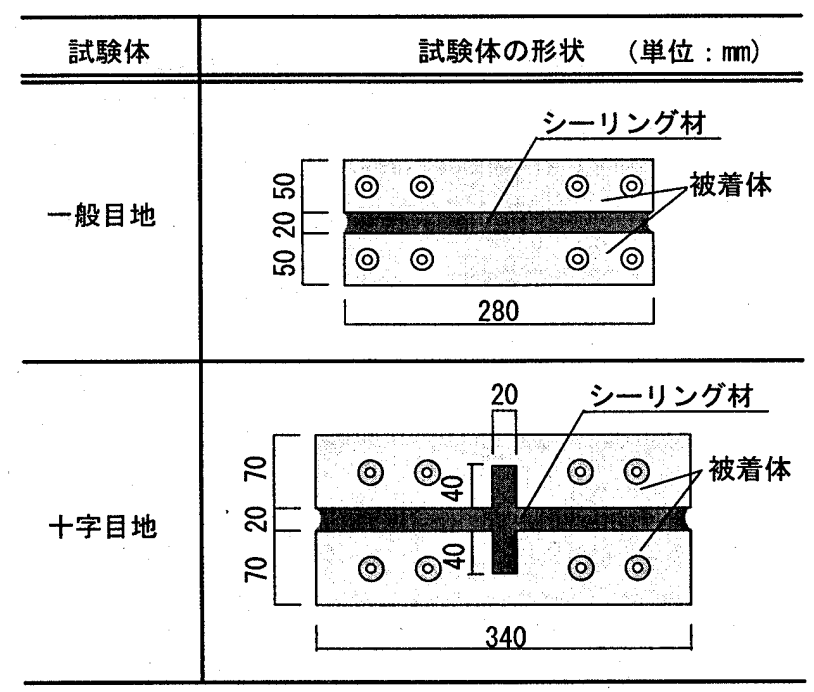

※シーリング材の目地幅 $20 \mathrm{~mm}$ 、目地深さ $13 \mathrm{~mm}$

図 2 試験体の種類

表 2 シーリング材の物理的性質

\begin{tabular}{|c|c|c|c|}
\hline 項目 & $\begin{array}{c}2 \text { 成分形 } \\
\text { シリコーン系 } \\
\text { (記号: SR-2) } \\
\end{array}$ & $\begin{array}{c}2 \text { 成分形 } \\
\text { 変成沙コー・系 } \\
\text { (記号 : MS-2) } \\
\end{array}$ & 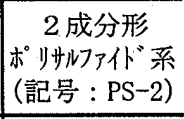 \\
\hline $50 \%$ 引張忘力 $\left(\mathrm{N} / \mathrm{mm}^{2}\right)$ & 0.13 & 0.13 & 0.11 \\
\hline 最大引張応力 $\left(\mathrm{N} / \mathrm{mm}^{2}\right)$ & 0.47 & 0.45 & 0.39 \\
\hline 伸び(\%) & 775 & 560 & 685 \\
\hline 色 & グレー & グレー & グレー \\
\hline
\end{tabular}

の長さ設定は、目地の端部の影響が生じる範囲をあらかじめ数值解析 10)-11) を行い検討してから図 2 に示す長さに設定した。断面寸法は基 本的な目地寸法である目地幅 $20 \mathrm{~mm}$ 、目地梁さ $13 \mathrm{~mm}$ とした。

シーリング材には、2成分形シリコーン系シーリング材（記号 : SR-2）、2成分形変成シリコーン系シーリング材（記号 : MS-2）、2 成分形ポリサルファイド系シーリング材（記号 : PS-2）を用いた。な お、表 2 に本研究で用いた 3 種類のシーリング材の物理的性質につい て示す。

試験体の作成方法は次の通りである。被着体にはアルミニウム材を 用いこれを 2 本平行に固定した。次いで発泡ポリエチレンバックア ップ材を挿入し、所定の深さに調節した後、プライマーを塗布し、シ ーリング材を充填した。シーリング材表面を被着体と同一平面となる ようにへらで仕上げた後、室温環境下 $\left(20 \sim 25^{\circ} \mathrm{C}\right)$ で 4 週間養生した。 また、バックアップ材は実験中にシーリング材を裏面から観察するた め、シーリング材が硬化後、これを除去した。なお、試験体数は各々 2個ずつとした。

\section{2 剪断疲労試験の概要}

疲労試験には、前報 ${ }^{1)-2)}$ と同様の剪断疲労試験機を使用した。シー リング目地に発生する剪断ムーブメントは、外力に対する外壁部材の 動きの違いすなわちスライド方式とロッキング方式の支持方法によ って多少異なる。しかし、本研究では十字目地試験体と一般目地試験 体に単純に繰り返し剪断ムーブメントが生じるスライド方式の支持 方法を用いて、耐剪断疲労性の検討を行なった。

剪断ムーブメントの振幅は、試験体目地幅 $(20 \mathrm{~mm})$ の $\pm 60 \%( \pm 12 \mathrm{~mm}) 、 \pm 100 \%( \pm 20 \mathrm{~mm})$ の3段階とした。なお、剪断 ムーブメントの与え方は、写真 1 に示すように試験体被着体の一方を 試験装置移動板に、もう一方を試験装置固定板に固定し、移動板を所 定の剪断ムーブメントになるように設定した。周期は 10 秒（6回/ 分）、試験温度は $20 \pm 2{ }^{\circ} \mathrm{C}$ で行なった。繰り返し回数については、亀 裂の発生する時までとし、亀裂の生じない場合は前報 ${ }^{1)-2)}$ では 10 万 $\left(=10^{5}\right)$ 回としたが、本研究では一般目地と十字目地の耐疲労性の差と ムーブメントの影響をより詳しく調べるために 100 万(=10 $\left.0^{6}\right)$ 回まで疲 労試験を行なった。なお、実際の建物に使用されるシーリング材は、 剪断ムーブメントと同時にウェザリングの影響も受ける。このため、 今回の試験において 100 万回の時点で健全であった試験体であって も、実際の屋外環境では、亀裂が発生する可能性がある。

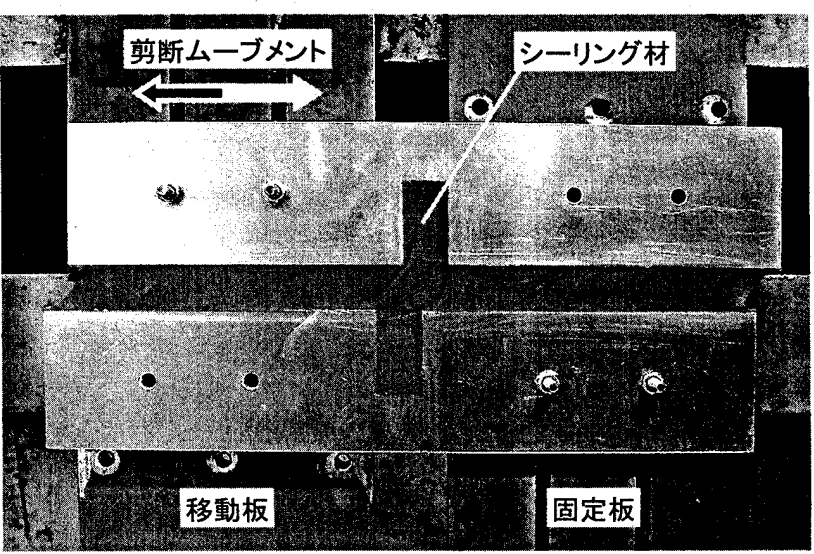

写真1 十字目地試験体に剪断ムーブメントを与えた時の状況 


\section{3 試験結果及び考察}

\subsection{1 龟裂の形態}

十字目地試験体に繰り返し剪断ムーブメントを与えた後の PS-2 シ ーリング材の亀裂発生状況を写真 2 に示す。一般目地については被着 体近傍で亀裂が発生し、被着体に沿って亀裂が進行した。また、十字 目地については、隅角部から亀裂が発生し、被着体に沿ってもしくは 斜めに亀裂が進行した。

\subsection{2 十字目地と一般目地の龟裂発生回数の比較}

繰り返し剪断ムーブメントを与えたときの一般目地と十字目地に おける亀裂発生回数の結果を図 3 に示す。全てのシーリング材におけ る剪断ムーブメント $30 \%$ 、及び一般目地 SR-2 で士 $60 \%$ では 100 万 回の時点で亀裂が発生せずその差が見られなかったが、MS-2 及び PS-2 における $60 \%$ と全てのシーリング材における士100\%では、十 字目地試験体の方が一般目地試験体より先に亀裂が発生した。亀裂発 生回数については、十字目地は一般目地に比べ一桁以上早かった。 3.3.3 十字目地における剪断ムーブメントと亀裂発生回数の関係

図 4に十字目地における各シーリング材ごとの剪断ムーブメント と亀裂発生回数の関係を示す。剪断ムーブメント士 $30 \%$ をちたた場合、 100 万回の時点で亀裂が発生しなかったため、剪断ムーブメントと亀 裂発生回数の正確な関係は得られなかった。しかし、100 万回での亀 裂が、剪断ムーブメント $30 \%$ 〜 $60 \%$ の間で発生すると考えた場 合、剪断ムーブメントが大きくなるほど、曲線の傾きが大きくなり、 その 1 回の変位に対するシーリング材の疲労に与える影響が大きく なると思われる。また、剪断ムーブメントがある程度小さくなると、 逆に曲線の傾きが小さくなり、耐疲労性が増すことがわかった。

\subsection{4 シーリング材の種類の影響}

シーリング材の性能の上では、SR-2 の而疲労性は、MS-2 及び PS-2 に比べ良好であることがわかった。ただし、図 5 に示すように、圾験

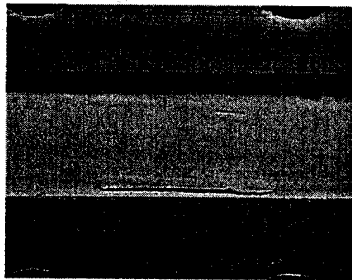

一般目地

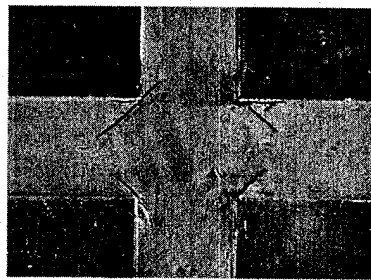

十字目地
写真2 亀裂の発生状況

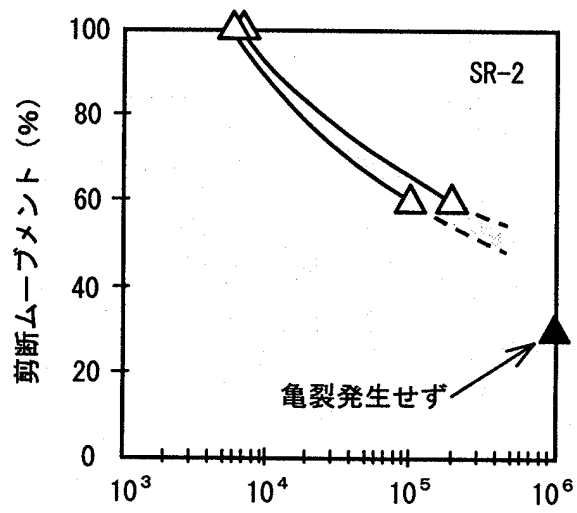

体 2 個の亀裂発生回数の平均值を用い一般目地に対する十字目地の 亀裂発生回数の比を求めた場合、どのシーリング材においても、隅角 部での亀裂発生回数の低下率は同程度の值を示した。これより、本実 験の範囲において、一般目地に対する十字目地の而疲労性は、シーリ ング材の種類に大きくは依存しないことがわかった。

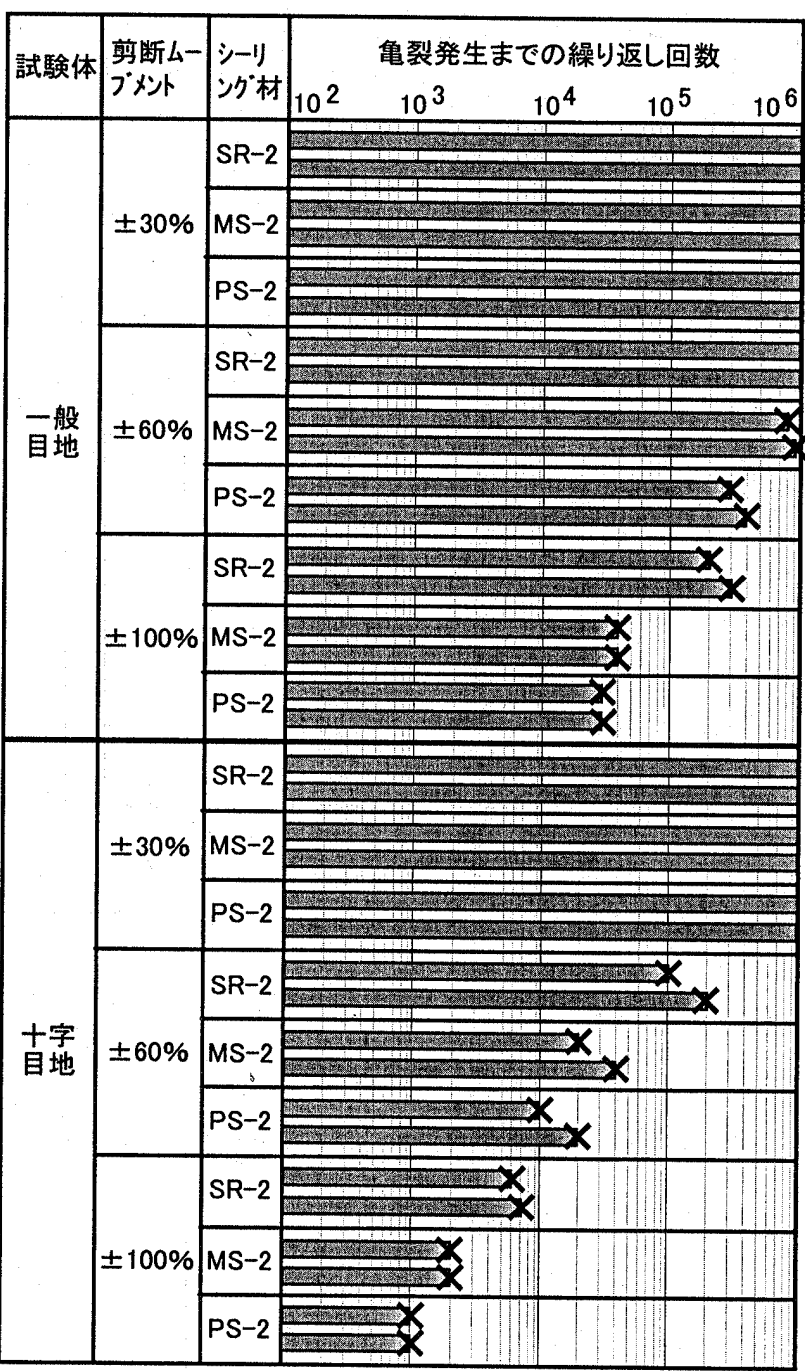

X 亀裂が発生したことを意味する。

図3一般目地と十字目地の亀裂発生回数

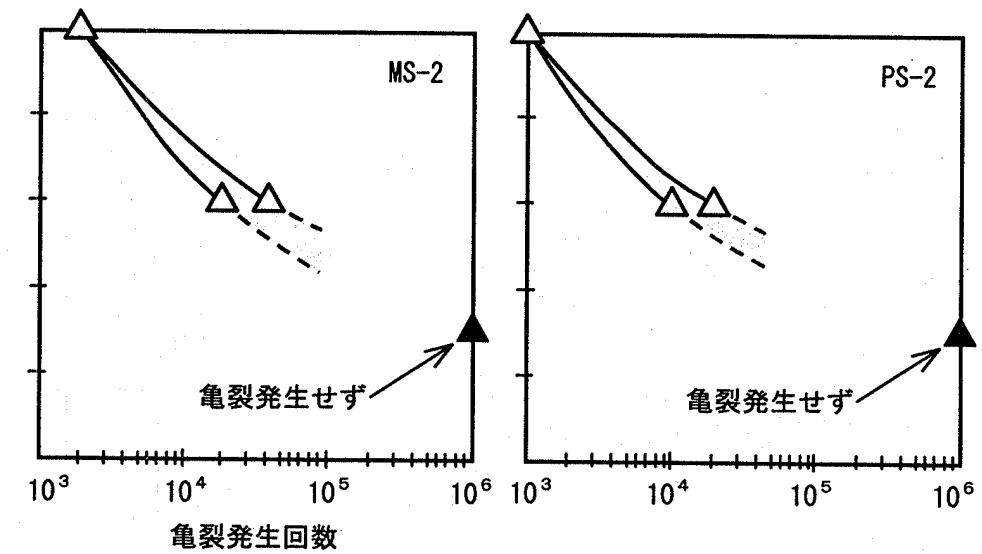

図 4 十字目地における剪断ムーブメントと亀裂発生回数の関係 


\section{4. 十字目地の応力分布解析}

\section{1 解析の概要}

\subsection{1 解析モデル}

一般目地に対する十字目地の耐疲労性の低下の影響を明らかにす る目的で、シーリング材の応力分布状態を FEM 数值解析 ${ }^{11)-12)}$ により 調べた。また、一般部の応力度と比べた場合の隅角部での応力集中 の度合い (応力集中率) についても検討した。

応力分布解析は、図 2 に示す疲労試験で用いた一般目地と十字目 地の試験体に対してモデル化したもので行い、その解析モデルを図 6に示す。また、解析モデルに対しては、引張りを受ける側の最大 忘力部に亀裂が入ることを想定したものとした。解析モデルの拘束 条件は、図 6 で示すように目地開放面以外の下側 4 面の斜線部を固 定する。変位条件は、上側 4 面に剪断変位 $+30 \%,+60 \%,+100 \%$ の変

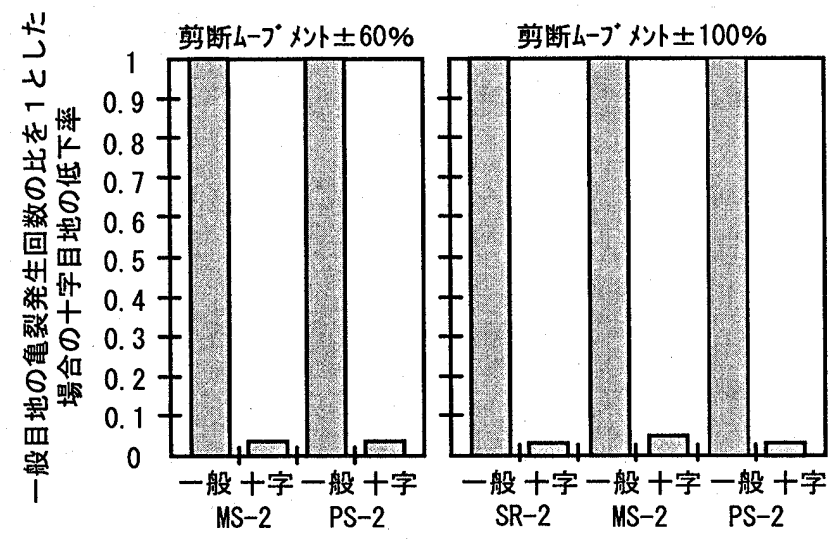

図 5 各シーリング材における十字目地の亀裂発生回数の低下率
位量を与えることとした。要素タイプは 2 次元モデル、8接点四角 形要素とし、最大応力部に最小の要素を割り当てた要素分割を行っ た。なお、要素の大きさによる解の収束性は確認している。

\subsection{2 数值計算上の諸条件}

シーリング材は、非線形性、大変形をもつ材料である。これらを 考慮した解析を行うために、歪エネルギ一関数を用いた。その関数 は、シート状試験体 $(90 \times 90 \times 2 \mathrm{~mm})$ を用い、単軸引張試験と 2 軸引張 試験より得られた各シーリング材の引張応力と伸び率の関係（図 7） から求めた。

\section{2 解析結果及び考察}

4.2.1 シーリング材の応力分布について

PS-2における剪断変位+ $60 \%$ を一例にとり、応力分布を調べた結 果を図8に示す。図8から一般目地に比べ、十字目地の隅角部で応

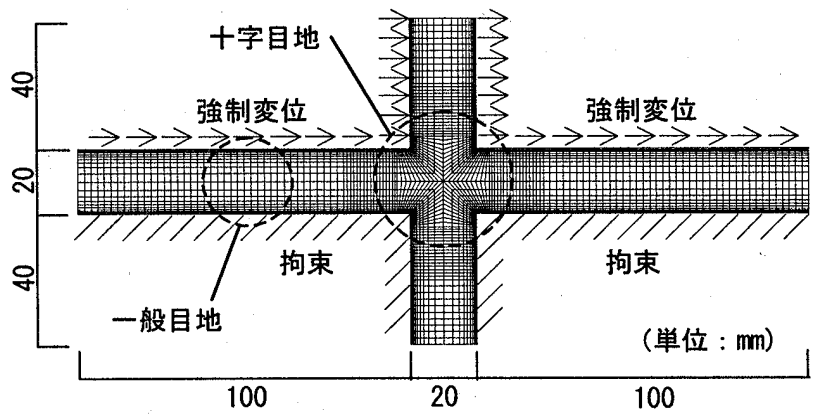

図 6 解析モデル
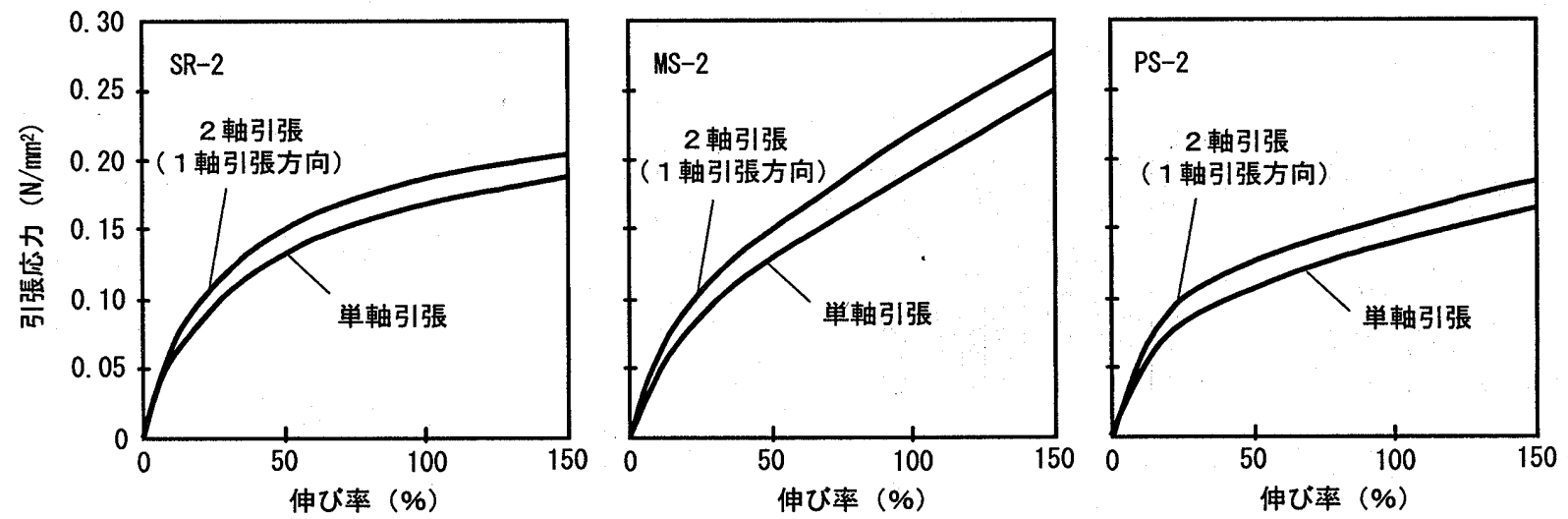

図 7 引張応力と伸び率

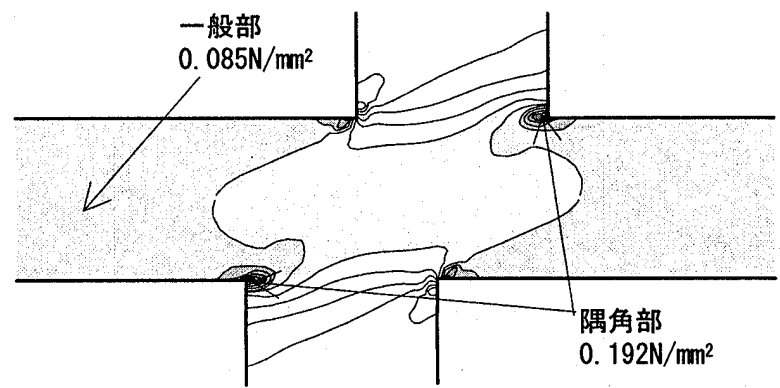

図 8 シーリング目地内の最大主応力度分布 (PS-2において、剪断変位 $+60 \%$ を与えた場合)

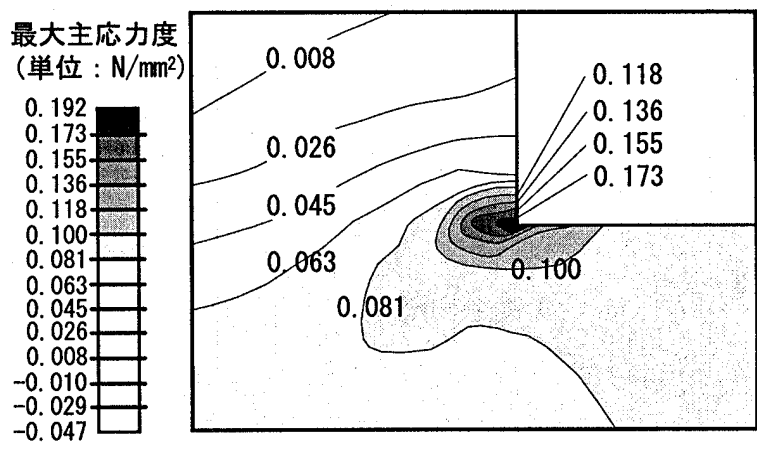

図 9 目地隅角部の応力状態 (PS-2ににおいて、剪断変位 $+60 \%$ を气えた場合) 

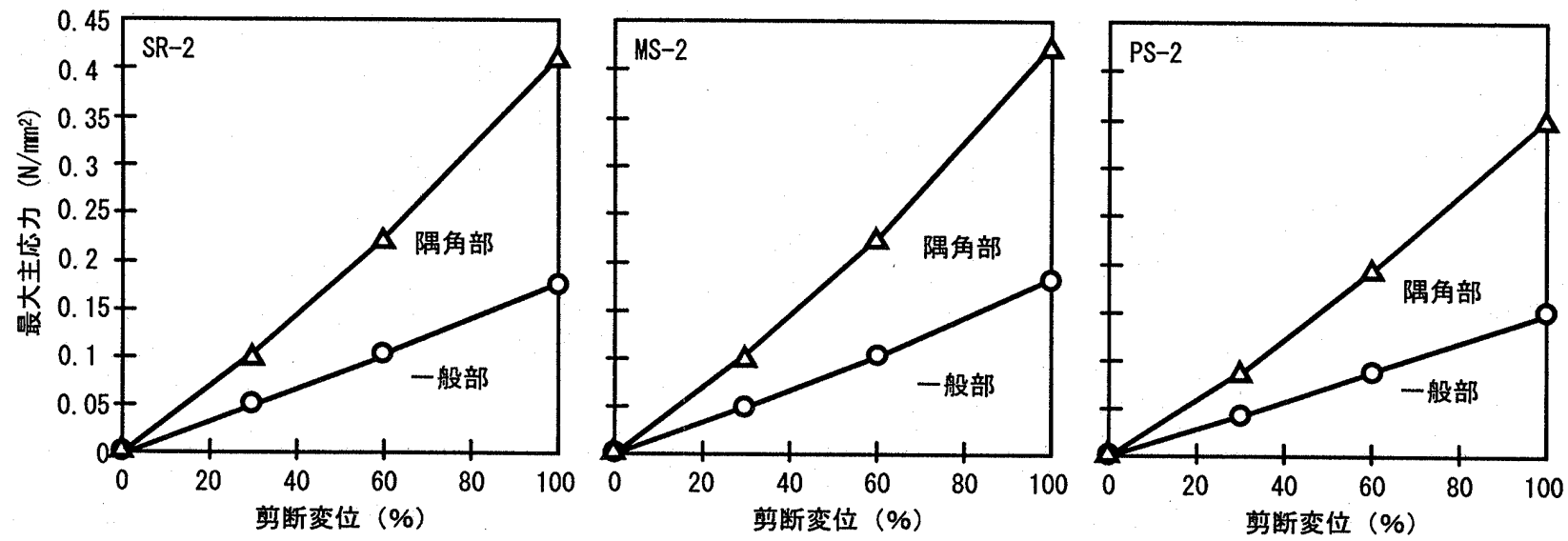

図10 一般部と隅角部における剪断変位と最大主応力との関係

力が集中することがわかる。この応力集中の生じている籄所を拡大 し図 9 に示寸と、その応力集中は、隅角部の非常に狭い領域で生じ ていることがわかる。

4.2.2 剪断ムーブメントに対する隅角部と一般部の応カレベルの比較

各シーリング材ごとに剪断変位を変えた場合の、最大主応力の変 化について図10に示した。各材料のモジュラスの違いにより応カレ ベルの絶刘值は多少異なるが、隅角部、一般部共に剪断変位が増せ ば、応力レベルが高くなり、その剪断変位に対する最大主応力の勾 配は、隅角部の方がより大きくなることがわかった。

\section{2.3 隅角部の応力集中について}

図10の剪断変位と最大主応力との関係をもとに、隅角部は一般部 に比べてどの程度応力集中するか調べた。なお、本研究では、この 応力集中の度合いを一般部に対する隅角部の応力集中率 $(\alpha)$ とし て定義し、式（1）を用いて検討した。

$$
\begin{aligned}
& \alpha=\sigma \mathrm{c} / \sigma_{0} \\
& \sigma \mathrm{c} \text { : 隅角部における最大主忘力 }\left(\mathrm{N} / \mathrm{mm}^{2}\right) \\
& \sigma \circ: \text { 一般部における最大主応力 }\left(\mathrm{N} / \mathrm{mm}^{2}\right)
\end{aligned}
$$

その結果、図11に示すように3種類のシーリング材は、所定の剪 断変位に対して、ほぼ同じような応力集中率を示した。また、その 大きさは、剪断変位 $+30 \%$ において 2.0 以上の值を示すとともに、剪 断変位が大きくなると、徐々に応力集中率も増加した。

\section{5. 十字目地の耐疲労性の評価}

\section{1 応力と象裂発生回数の関係}

十字目地が一般部より耐剪断疲労性が劣るのは、解析結果でもわ かるように、応力レベルの大きさに起因すると考えられる。そこで、 繰り返し剪断ムーブメントを与えたときの一般部と隅角部の最大主 応力と、亀裂発生までの繰り返し回数との関係について調べた。 の結果、図12に示すようにSR-2では、亀裂が発生しなかった試験体 が多かったため、明確に変化が見られなかったが、MS-2及びPS-2に ついては、隅角部と一般部の亀裂発生回数は 領域をもった一つの 曲線で表せることができ、态力が高くなるほど曲線の傾きは大きく なり、隅角部はより早い段階で亀裂が発生しやすくなることがわか った。

\section{2 一般部と隅角部における剪断ム一ブメントと亀裂発生回数の関係}

JASS $8^{12)}$ では各種シーリング材ごとに設計剪断変形率（目地幅に

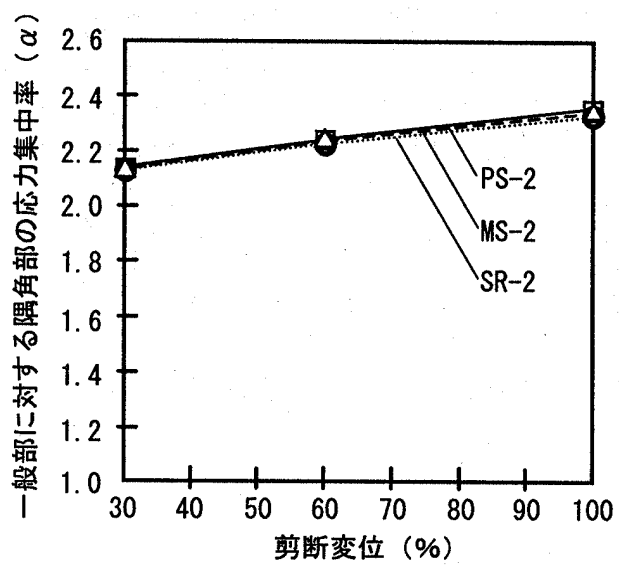

図11 剪断変位と応力集中率 の関係

対する剪断変形の割合）を設定しているが、それぞれの值は、標準 となる一般目地に対する要求性能を示しているため、同時に隅角部 がどの程度の性能をもつかは不明である。そこで、所定の剪断ムー ブメントを与えた場合、一般部に対して隅角部はどの程度耐疲労性 が低下するのかを、5.1の応力と亀裂発生回数の関係をもとに同一の 式を用いて数式化を試みた。まず、応力と亀裂発生までの繰り返し 回数の関係について調べた。式（1）から、

$$
\sigma \mathrm{c}=\alpha \cdot \sigma \mathrm{o}
$$

次に、図10から各シーリング材における一般部での剪断変位と最 大主応力の関係を求めると、ほぼ式（3）で近似できる

SR-2: $\quad \sigma 0=0.0018 \mathrm{~s}$

MS-2: $\quad \sigma \mathrm{o}=0.0018 \mathrm{~s}$

PS-2: $\quad \sigma 0=0.0015 \mathrm{~s}$

$$
s: \text { 剪断変位 }(\%)
$$

また、応力と亀裂発生までの繰り返し回数の関係については、比 較的多く用いられているBasquin式 ${ }^{13)}$ をとにして関係を求めた。

$$
\mathrm{N}=\mathrm{A} \cdot \sigma \mathrm{c}^{-\mathrm{B}} \cdot(\mathrm{B}>0)
$$

\section{$\mathrm{N}$ : 亀裂発生回数 A、B : 係数}

5.1 で述べたように、応力と亀裂発生回数の関係は領域をもった一 つの曲線の中で表されるが、目地設計の観点からより安全側をとって、 

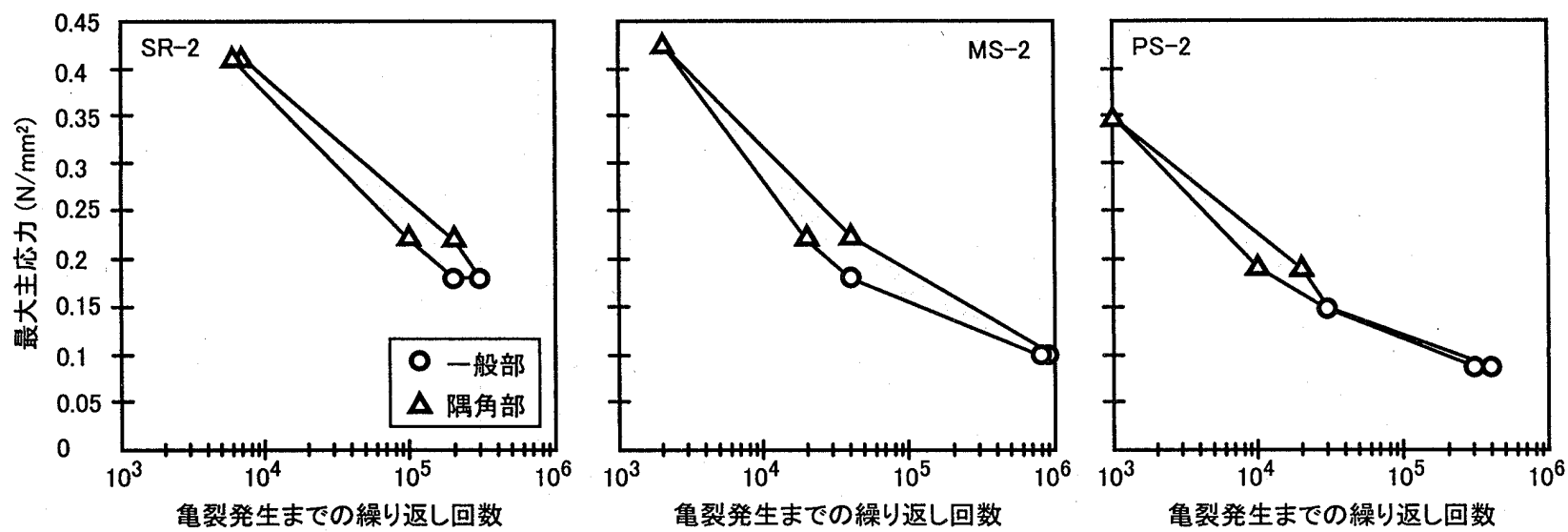

図12 最大主応力度と亀裂発生回数の関係

表 3 一般部と隅角部における 亀裂発生回数亡剪断ムーブメントの関係

\begin{tabular}{c|c}
\hline シーリング材 & 隅角部と一般部の亀裂発生回数の予測式 \\
\hline \hline SR-2 & $\mathrm{N}=146(\alpha \cdot 0.0018 \mathrm{~s})^{-4.24}$ \\
\hline $\mathrm{MS}-2$ & $\mathrm{~N}=15.5(\alpha \cdot 0.0018 \mathrm{~s})^{-4.89}$ \\
\hline $\mathrm{PS}-2$ & $\mathrm{~N}=1.81(\alpha \cdot 0.0015 \mathrm{~s})^{-5.31}$ \\
\hline
\end{tabular}

亀裂発生回数の低い值をもとに係数を求めた。これより、各シーリン グ材において、

$$
\begin{array}{ll}
\text { SR-2: } & \mathrm{N}=146 \sigma \mathrm{c}^{-4.24} \\
\text { MS-2: } & \mathrm{N}=15.5 \sigma \mathrm{c}^{-4.89} \\
\text { PS-2: } & \mathrm{N}=1.81 \sigma \mathrm{c}^{-5.31}
\end{array}
$$

として、応力と亀裂発生回数の関係を求めることができる。ここで、 式（2），(3），(5) より、各シーリング材において一般目地およ び十字目地に同じ剪断ムーブメントが生じた場合の亀裂発生回数の 関係について、表 3 のように式を求めることができる。この表 3 の式 によれば、一般部と隅角部における亀裂発生回数Nは、剪断変位 $\mathrm{s}$ と 応力集中率 $\alpha$ との関係で示される。 $\alpha=1$ の場合一般部の亀裂発生回 数を表すが、隅角部の場合には $\alpha$ の值が大きいほどより早い段階で亀 裂が発生する。目地設計では、隅角部における $\alpha$ の值をできるだけ 1 に近づけることが、耐剪断疲労性を増加させるために必要になってく る。この問題については今後の課題とする。なお、今回目地幅 $20 \mathrm{~mm}$ の場合の耐疲労性について検討したが、実際の建物に適用される目地 幅は、 $20 \mathrm{~mm}$ に対して極端に大きくなったり、小さくなったりしない ため、目地幅が変化しても、おおよそではあるが表 3 で示す式により 亀裂発生回数を予想することができると考えられる。

\section{6. まとめ}

本研究では、シーリング目地の交差部における耐剪断疲労性につい て検討し、次のような結果及び知見が得られた。

（1）剪断疲労試験結果により、十字目地の隅角部は一般部に比べ 早い段階で亀裂が発生し、亀裂発生回数の低下率は 3 種類のシ ーリング材共に同様の傾向を示した。

（2）数值解析の結果、十字目地の隅角部の非常に狭い領域で応力
が集中した。また、一般部に対する隅角部の応力集中率は、3 種類のシーリング材共に所定の剪断ムーブメントに対してほ ぼ同じ同じ值を示すとともに、剪断変位が増すごとに徐々に大 きくなうた。

（3）応力を基集にして考えると、一般部と隅角部の亀裂発生回数 は領域をもった一つの曲線で表せることができる。また、応力 が高くなるほど、曲線の傾きは大きくなり、隅角部ではより亀 裂が発生しやすいため、耐剪断疲労性を低下させる恐れがある ことがわかった。

本研究は、文部科学省科学研究費補助金奨励研究 (A)「各種シ一 リング材の而疲労性の比較と目地設計への適用」によりました。

\section{参考文献}

1）田中等二、宮内博之、平居孝之 : シーリング材の剪断疲労に及ぼす断面寸法と 形状の影響 ; 日本建築学会構造系論文集、第511号、pp. 47-52、1998.9

2）田中享二、宮内博之: シーリング目地の新しい剪断疲労試験方法の提案、及び それを用いての目地形状の影響の検討; 日本建築学会構造系論文集、第522号、 pp. 7-12、1999. 8

3) Hiroyuki Miyauchi and Kyoji Tanaka : New Shear Fatigue Test Method for Building Sealants and Some Tests of Sealants with Various Shapes; Durability of Building and Construction Sealants, Proceedings of the Third International RILEM Symposium, pp. 275-285, 2000

4) F. W. Shisler III and J. M. Klosowski: Sealant Stresses in Tension and Shear; Building Sealants, Materials, Properties and Performance, ASTM STP1069, American Society for Testing and Materials, pp. 95-107, 1990

5) J. Iker and A. Wolf : Secondary Stresses Induced by Shear Movement in Structural Glazing Sealants; Materials and Structures, vol. 25, pp. 137-144, 1992

6) J. M. Klosowski and A. Wong: Shear Component of a Structural Sealant Glazing Joint; Science and Technology of Building Seals, Sealants Glazing and Waterfroofing, ASTM STP 1186, American Scoiety for Testing and Materials, pp. 97-105, 1992

7) M.S. Zarghamee, T.A.Schwartz and M.Gladstone: Seismic Behavior of Structural Silicone Glazing; Science and Technology of Building Seals, Sealants, Glazing and Waterproofing, ASTM STP 1286, American Society for Testing and Materials, pp. 46-59, 1996

8）宮内博之、田中享二 : シーリング目地コ一ナ一部の耐疲労性評価 ; 日本建築学 会大会学術講演梗概集 $[\mathrm{A}] 、$ pp. 69-70、1999

9）宮内博之、田中呩二：ムーブメントに対するシーリング目地隅角部と目地一般 部の酎摭労性の評価 ; 日本建築学会大会学術講演梗概集 [A] 、pp. 47-48、2000

10) Ogden, J. T. : Finite Elements of Nonlinear Continua, MoGraw-Hill, New York, 1972

11) Twizell, E. H. and R. W. Ogden: Non-linear Optimization of the Material Constants in Ogden's Stress-Deformation Function for Incompressible Isotropic Elastic Materials ; J. Austral. Math. Soc. Ser. B, vol. 24, 1983

12）日本建築学会：日本建築学会標準仕様書 JASS 8防水工事、pp. 283、1993

13）河本実 : 金属の疲労、朝倉書店、1962 